\title{
Study the Market Accessibility of Farmers Supported Through Grant by District Livestock Service Office in Lamjung
}

\author{
Abhishek Pudasaini*, Santosh Subedi, Manoj Sharma, Prabhakar Joshi and Yuwaraj Bhandari \\ Agriculture and Forestry University, Rampur Chitawan, Nepal \\ *Corresponding Author: Abhishek Pudasaini, Agriculture and Forestry University, Rampur Chitawan, Nepal.
}

Received: March 22, 2019; Published: June 03, 2019

DOI: $10.31080 /$ ASAG.2019.03.0507

\begin{abstract}
District Livestock Service Office (DLSO), Lamjung has been providing the grants for raising life standard of the poor farmers, women, ethnic groups through quality production and their commercialization in different sectors via goat, dairy, pig and poultry on individual and group basis. A study was conducted among the farmers who were supported by DLSO to identify the marketing condition of their product, the problems they faced along with further expectation from DLSO in 18 VDCs and municipalities from February to June 2017. Data was collected by semi structured questionnaire among 142 respondents through purposive sampling and analysis was done by Statistical Package for Social Science (SPSS 20.0) and Microsoft Excel. The study revealed that 79\% of farmers had good access of market and they could sell meat (70\%) easily followed by milk product. Similarly, maximum farmers (76.8\%) sold their product by themselves in which Janajati people govern 46.8\%, with 30.3\% Dalit and 22.9\% Brahmin. The main problem seen in livestock rearing was transportation (50\%) followed by price fluctuation (13.4\%) and storage (8.5\%). In cattle farming, the major problem was in storage (60\%) of dairy products. Most of the farmers expect to access the safe transportation (59.2\%) for selling their products from DLSO. Poultry raising farmers (14.8\%) had expected to promote village tourism while the pig rearing farmers (12\%) wanted to have proper management of market within the district.
\end{abstract}

Keywords: Expectation; Grant; Purposive; SPSS

\section{Introduction}

Livestock keeping has been an integral part of crop agriculture. Around $65 \%$ of the population is engaged in agriculture, which is still the largest sector of economy having the share of around $31.6 \%$ of the GDP and share of Livestock subsector to AGDP is $26.8 \%$, whereas livestock sector alone contributes $11 \%$ to National GDP [1]. Cows and buffalo are raised for draft power (oxen/male buffalo), production of animal manure and the supply of animal protein (cows for milk, and buffalo for both milk and meat). Goats, poultry and other animals are also raised but the large animals are predominant [2]. District Livestock Service Office (DLSO) situating in Besishahar municipality of Lamjung district has been providing the farmers with subsidy either in the monetary form or by providing required materials for raising the life standard of farmers. The objectives of the study were to identify the marketing status of livestock, the problems faced by the farmers in various sectors of marketing along with the further expectation from DLSO.

\section{Methodology}

The survey was conducted in 18 VDCs and municipality altogether of Lamjung district of Nepal from February to June 2017 in 4 sectors via goat, pig, poultry and dairy animals by collecting primary information related to marketing of 142 samples by using purposive sampling through questionnaire. There were 7 groups and 17 individual farmers in goat sector, 6 individual in pig sector, 5 individuals in cow sector, 8 in buffalo and 3 groups in poultry sector. The collected data was then analysed using SPSS ver. 20 and MS Excel 2007. 


\section{Result and Discussion}

- Ethnicity of respondent and grant spent titles: The major responding farmers of our survey were found to be Brahmin and Chhetri, Janajati and Dalit each covering 19.7\%, 52.1\% and $28.2 \%$ respectively. Out of the total grant provided to the farmers from DLSO, 55.6\% was spent to purchase animal, $40.8 \%$ was spent on animal housing, $2.1 \%$ on feed and $0.7 \%$ each on slaughter house and transportation.

- Access of market: $79 \%$ of the farmers had easy access to the market while the remaining $21 \%$ had difficulty in the access to market. The easiest market was found to be of meat which was $70 \%$ followed by milk products $13 \%$ and remaining $17 \%$ of market selling was not decided.

- Collector of product and Ethnicity: Maximum (76.8\%) people have sold their product by themselves of which $46.8 \%$ is contributed by Janajati. Only Brahmin and Chhetri sell their product through cooperatives. Similarly $14.8 \%$ people don't sell their product in market. As the chi square value is more than $5 \%$, ethnicity is not significant with the collectors for selling the products.

- Problem faced during marketing: The major problem faced during marketing was of transportation which was found to be $50.7 \%$, followed by price fluctuation $13.4 \%$, then by storage facilities $8.5 \%$ and $27.5 \%$ were found to have faced no problems during marketing. FAO [3] reported that there is lack of transportation facilities for livestock esp. for goats as they are transported in the bus rooftops. The supply constraints are also associated with collection difficulties because of scattered production pockets, difficult mountainous terrain, lack of road connectivity and lack of transportation facilities. Majority of livestock markets are located in the plains and goat raising pockets are often in the hills and mountains, existing market networks could not provide adequate market access to the meat goats [4]. Similar result was obtained by Paudel., et al. [5].

Market problems in the particular sector of grant

\begin{tabular}{|c|c|c|c|c|c|c|}
\hline Livestock & No problem & Transportation & Storage & $\begin{array}{c}\text { Market } \\
\text { fluctuation }\end{array}$ & Others & Out of \\
\hline Cow & 0 & 40 & 60 & 0 & 0 & 3.5 \\
\hline Goat & 10.3 & 70.1 & 1.1 & 17.2 & 1.1 & 61.3 \\
\hline Poultry & 80 & 0 & 20 & 0 & 0 & 24.6 \\
\hline Pig & 0 & 42.9 & 14.3 & 42.9 & 0 & 4.9 \\
\hline Buffalo & 12.5 & 75 & 0 & 12.5 & 0 & 5.6 \\
\hline Pearsons square & & & & & & $\mathrm{R}<0.001^{* *}$ \\
\hline
\end{tabular}

Table 1: Problems of market in different sector of grant.

Source: Own survey data

Kharel and Pradhan [6] has reported that the problem faced by the goat-raising industry of Nepal were the inadequate market and marketing facilities, inaccessible, distant markets as well as poor marketing facilities. The people who were granted for cow farming face problem of storage of milk and milk product and transportation while the goat rearing farmers face major problem of transportation. This is supported by the result of Joshi and K.C. [2] in which problem of quality in milk collection will be solved to a greater extent if chilling of milk can be performed as close to the milk production point as possible. Milk collection involves the maintenance of milk quality by maintaining the cold chain from the point of production until the point where the milk reaches the processing plant. In pig, the most common problem was in transportation and market fluctuation. Premy., et al. [7] identified some major problems in pig marketing that were lack of specialized market and market infrastructures, weak linkage between traders and producers, lack of market lead production, lack of coordination, no alignment of market intelligence with pig production package, lack of information on domestic and international market, lack of abattoir facilities etc which could be the key areas for intervention in future. Similar problems was reported by PEAN [8]. 
Expectation in different sectors from DLSO

\begin{tabular}{|c|c|c|c|c|c|c|}
\hline $\begin{array}{c}\text { Sector Wise expected } \\
\text { Improvement }\end{array}$ & Cow & Goat & Poultry & Pig & Buffalo & Out of \\
\hline $\begin{array}{c}\text { Promoting village } \\
\text { tourism }\end{array}$ & 0 & 0 & 100 & 0 & 0 & 14.8 \\
\hline Road access & 3.6 & 72.6 & 16.7 & 0 & 7.1 & 59.2 \\
\hline Price determination & 10 & 80 & 0 & 0 & 10 & 14.1 \\
\hline Market management & 0 & 58.8 & 0 & 41.2 & 0 & 12 \\
\hline Pearson square & & & & & & $\mathrm{R}<0.001^{* *}$ \\
\hline
\end{tabular}

Table 2: Expectation of farmers in different sectors from DLSO.

Source: Own Survey data

Most of the farmers expect to access the safe transportation (59.2\%) for selling their products from DLSO. Poultry raising farmers $(14.8 \%)$ had expected to promote village tourism while the pig rearing farmers $(12 \%)$ wanted to have proper management of market within the district. NCPS [9] also give some suggestions for establishing market centres to sell chicken and egg to the government.

\section{Conclusion}

Farmers are getting grants from DLSO, Lamjung in various sectors. Transportation was the major problem in these farmers and expecting the road accessibility for proper marketing of their products.

\section{Bibliography}

1. AICC. Krishi Diary 2072. Agricultural Information and Communication centre, Lalitpur, Nepal (2014).

2. Joshi DD and TKC. An overview of smallholder dairy production and marketing in Nepal. "Smallholder dairy production and marketing-Opportunities and constraints". Proceedings of a South-South workshop held at National Dairy Development Board (NDDB) Anand, India (2001): 33-46.

3. FAO. Meat- led Quality Meat Production and Processing. Food and Agriculture Organization of the United Nation. United Complex. Pulchowk, Nepal (2010).
4. Premy KP and MP Aryal. "Constraints in Goat Marketing and Strategies For Improving Marketing Network And Linkages. Proceedings of the National Workshop on Research and Development Strategies for Goat Enterprises in Nepal (2013): 102-113.

5. Paudel KP., et al. "Goat Meat Value Chain in Nepal: Current Status and Key Interventions". Proceedings of the National Workshop on Research and Development Strategies for Goat Enterprises in Nepal (2013): 133-146.

6. Kharel M and SL Pradhan. "Goat meat production in Nepal". Goat meat production in Asia: proceedings of a workshop held in Tando Jam, Pakistan (1988): 152-160.

7. Premy KP., et al. "Current Status of Marketing of Pig and Pork in Nepal. Proceedings of the First National Workshop on Pig and Pork Industry in Nepal (2013): 117-123.

8. PEAN. Pig Entrepreneur Association Nepal. Analysis of Pig and pork market system in Nepal. CEAPRED/SAMARTH NMDP Pig Sector Project (2016).

9. NCPS. Survey Report and Major findings. Nepal commercial Poultry Survey. Secretariat of National Planning Commission. Central Bureau of Statistics. Kathmandu (2015).

\section{Volume 3 Issue 7 July 2019}

(C) All rights are reserved by Abhishek Pudasaini., et al. 